Institute of $\mathbf{F}_{\text {ood and }} \mathbf{A}_{\text {gricultural }} \mathbf{S}_{\text {ciences }}$

\title{
2003 Handbook of Employment Regulations Affecting Florida Farm Employers and Workers: Field Sanitation and Drinking Water [Federal] ${ }^{1}$
}

\author{
Leo C. Polopolus, Michael T. Olexa, Fritz Roka, and Carol Fountain ${ }^{2}$
}

\section{Purpose}

To provide federal standards of field sanitation and drinking water for hand laborers.

\section{Who Must Comply}

Employers who currently employ or have employed during the past twelve months at any one time eleven or more employees engaged in hand labor operations in the field must provide toilets, hand washing facilities, and drinking water to such employees at no cost to the employees.

\section{Definitions}

- Handwashing facility. This means a facility providing a basin, container, or outlet with an adequate supply of potable water, soap, and single-use towels.

- Potable water. This means water that meets the standards for drinking purposes of the state or local authority having jurisdiction or water that meets the quality standards prescribed by the U.S. Environmental Protection Agency's national Interim Primary Drinking Water Regulations, published in 40 C.F.R., Part 141.

- Toilet facility. This means a fixed or portable facility designed for the purpose of adequate collection and containment of the products of

\footnotetext{
1. This is EDIS document FE398, a publication of the Department of Food and Resource Economics, Florida Cooperative Extension Service, Institute of Food and Agricultural Sciences, University of Florida, Gainesville, FL. Published July 2003. This information is included in Circular 1200, Handbook of Employment Regulations Affecting Florida Farm Employers and Workers. First published February 1992 as Circular 1043 . Revised December 2002 as Circular 1200. Please visit the EDIS website at http://edis.ifas.ufl.edu.

2. Leo C. Polopolus, Professor Emeritus, Department of Food and Resource Economics, University of Florida, Gainesville, FL; Michael T. Olexa, Professor, Department of Food and Resource Economics, University of Florida, Gainesville, FL; Fritz Roka, Associate Professor, Department of Food and Resource Economics, Southwest Florida Research and Education Center, Immokalee, FL; and Carol Fountain, Assistant Editor, Department of Food and Resource Economics, University of Florida, Gainesville, FL; Florida Cooperative Extension Service, Institute of Food and Agricultural Sciences, University of Florida, Gainesville, FL.

This document is designed to provide accurate, current, and authoritative information on the subject. However, since the laws, administrative rulings, and court decisions on which it is based are subject to constant revision, portions of this publication could become outdated at any time. This publication is distributed with the understanding that the authors are not engaged in rendering legal or other professional advice, and the information contained herein should not be regarded as a substitute for professional advice. For these reasons, the utilization of these materials by any person constitutes an agreement to hold harmless the authors, the Institute of Food and Agricultural Sciences, and the University of Florida for any liability claims, damages, or expenses that may be incurred by any person as a result of reference to or reliance on the information contained in this publication.
}

The Institute of Food and Agricultural Sciences is an equal opportunity/affirmative action employer authorized to provide research, educational information and other services only to individuals and institutions that function without regard to race, color, sex, age, handicap, or national origin. For information on obtaining other extension publications, contact your county Cooperative Extension Service office. Florida Cooperative Extension Service/Institute of Food and Agricultural Sciences/University of Florida/Christine Taylor Waddill, Dean. 
both defecation and urination which is supplied with toilet paper adequate to employee needs. Toilet facility includes biological, chemical, flush and combustion toilets, and sanitary privies.

\section{Employer Responsibilities}

- Provide toilets and handwashing facilities:

- One toilet facility and one handwashing facility for every twenty employees or fraction thereof.

- Toilet facilities shall be adequately ventilated, screened, and constructed to ensure privacy with self-closing doors that can be closed and latched from the inside.

- Toilet and handwashing facilities shall be accessible to employees and in close proximity to each other. Facilities shall be located within a one-quarter mile walk of each hand laborer's place of work in the field.

- Where, because of terrain problems, it is unfeasible to locate facilities within the one-quarter mile distance, the facilities shall be located at the closest vehicular access to the field.

- Provide potable drinking water which is readily accessible to all employees:

- The water shall be suitably cool and in sufficient amounts, taking into account the air temperature, humidity, and the nature of the work performed, to meet the needs of all employees.

- The water shall be dispensed in single-use drinking cups or by fountains. The use of common drinking cups or dippers is prohibited.

- Maintain potable drinking water, toilets, and handwashing facilities in accordance with appropriate public health sanitation practices:

- Drinking water containers shall be constructed of materials that maintain water quality, shall be refilled daily or more often as necessary, shall be kept covered, and shall be regularly cleaned.

- Toilet facilities shall be operational and maintained in a clean and sanitary condition.

- Handwashing facilities shall be refilled with potable water as necessary to ensure an adequate supply and shall be maintained in a clean and sanitary condition.

- Disposal of waste from facilities shall not cause unsanitary conditions.

- The employer shall notify each employee of the location of drinking water and sanitation facilities and provide employees with reasonable opportunities during the work day to use them.

- It is the employer's responsibility to inform each employee of the importance of each of the following good hygiene practices to minimize exposure to the hazards in the field of heat, communicable diseases, retention of urine, and agricultural residues:

- Use the water and facilities provided for drinking, handwashing, and elimination.

- Drink water frequently, especially on hot days.

- Wash hands both before and after using the toilet.

- Urinate as frequently as necessary.

- Wash hands before eating and smoking.

\section{Exemptions}

- Employers who currently employ ten or fewer employees in hand-labor field operations and who have not employed, during the past twelve months at any one time, eleven or more employees engaged in hand-labor field operations.

- Toilet and handwashing facilities are not required for employees who perform field work for a period of three hours or less during the day, including transportation time to and from the field. 
- Activities such as logging operations, the care and feeding of livestock, or hand labor operations in permanent structures (e.g., canning facilities or packing houses) are not included in hand labor operations.

\section{Additional Information}

- Labor Bulletin No. 450, Florida Fruit and Vegetable Association, Orlando, FL, July 29, 1987.

- 29 C.F.R., Part 1928.110.

- Federal Register, Vol. 52, No. 84, Friday, May 1, 1987 (Rules and Regulations).

\section{Responsible Agency}

\section{U.S. Department of Labor}

(See EDIS document FE408, Occupational Safety and Health Act (OSHA) [Federal].) 